\title{
Birth of a Subject Heading
}

\section{Anna M. Ferris}

This paper illustrates the process by which a subject heading is created within the controlled vocabulary of the Library of Congress Subject Headings (LCSH). The author details the steps involved in proposing a subject heading for inclusion in the Subject Authority File at the Library of Congress using two case studies as examples, one in which the subject heading was accepted into the LCSH system and one in which the subject heading was rejected despite being revised and resubmitted.

A original cataloger's work, as defined by Chan, involves "the preparation A of a cataloging record without the assistance of outside cataloging agencies; cataloging in-house, from scratch . . . with fully original cataloging restricted to items for which no outside record is available."1 Very often, original catalogers working in academic libraries are required to create original bibliographic records for newly published works that deal with cutting-edge research or emerging concepts within a specific discipline. In doing so, they are also performing the most fundamental task in original cataloging - classification-which entails "the systematic arrangement by subject ... of catalogue and index entries in the manner which is most useful to those who read or who seek a definite piece of information." Therefore, an essential aspect of classification is the creation of new subject headings. Chan defines a subject heading as a term that denotes the subject under which all material on that subject is entered into a catalog. ${ }^{3}$ Undoubtedly, this aspect of the original cataloger's work is significant in that it provides a twofold benefit. First, new subject headings help single out the unique content of items being cataloged, especially as needed to describe cutting-edge research and emerging concepts; second, new subject headings enable researchers to identify and locate works that deal with those new topics that are most relevant to their research needs. Proposals by original catalogers for new subject headings to be included in the Library of Congress (LC) Subject Authority File are made possible through SACO, LC's Subject Authority Cooperative Program.

Proposing and submitting new subject headings is a complex yet highly gratifying process. Many original catalogers who have done so remember the first subject heading they proposed that was added to the Library of Congress Subject Headings (LCSH), "the most comprehensive non-specialized controlled vocabulary in the English language.". However, the complexities of the subject heading proposal process, compounded by LCSH's century-old reputation, can be quite intimidating. In this paper, the author demonstrates how LC's subject heading proposal policies and procedures have evolved into a readily accessible and convenient system that guides and encourages catalogers at each stage of the process. Additionally, this paper highlights the profound effect that original catalogers have on bringing about the needed changes to LCSH's structure as they work with LC subject specialists and the SACO Cooperative Programs

(COOP) Section.
Anna M. Ferris (anna.ferris@colorado Manuscript submitted December 29, 2016; returned to author March 20 , 2017, for revision; revised manuscript submitted April 11, 2017; returned to author July 22, 2017, for minor revision: revised manuscript submitted July 24 2017; accepted for publication September 18, 2017. 


\section{Literature Review}

Subject headings and controlled vocabularies have been prevailing topics in the literature in recent times, especially with the comparison between controlled vocabularies and folksonomies, or entry vocabularies (user-supplied terms or keywords), which are referred to as such for their function as "entry points into the catalog." Excellent literature reviews focusing on this comparison have been done by Gross, Taylor, and Joudrey; Strader; and Schwing, McCutcheon, and Maurer. ${ }^{6}$ The consensus in these papers supports the coexistence or the "complementariness" of controlled and uncontrolled vocabularies in the catalog, especially for searching new research topics that may appear in electronic theses and dissertations (ETDs) or in scholarly journal articles. Additionally, while ETDs have proven to be valuable sources for establishing new subject headings because they present "contemporary research in

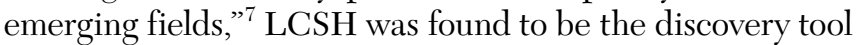
that provides "more effective subject access four times as often as will title keywords."

As the leading library standard for formulating and assigning subject headings, LCSH has been the focus of these discussions for more than one hundred years, receiving an equal share of criticisms and praise from not only catalogers but also other information professionals, including educators, researchers, indexers, and public services librarians. Radical Cataloging is an especially relevant collection of essays, edited by K. R. Roberto, that highlights the pros and cons related to the issues with LCSH that working catalogers face every day. ${ }^{9}$ Among the criticisms, the literature notes that LCSH is an expensive and time-consuming system to maintain, or is too complex for patrons to use, along with other issues such as its lack of currency or its biased use of language. ${ }^{10}$ Calhoun's 2006 report to LC introduces the idea that the LCSH should be eliminated, stating, "There were no strong endorsements for LCSH."

The discussions related to lack of currency or biased language in LCSH have evolved considerably since the early 1970s when Berman published Prejudices and Antipathies: A Tract on the LC Subject Headings Concerning People, pointing out the distinct Euro-American bias used in certain pejorative and questionable LCSH headings. ${ }^{12}$ Through the years, LC has been receptive to addressing complaints and has updated headings as needed to maintain currency by introducing natural language headings that patrons would expect to find in newer publications. Regarding the LGBT-related headings being incorporated into LCSH, Johnson confirms that "including more voices in the process of growing and revising the LCSH . . . has augmented the vocabulary with numerous headings pertaining to GLBT people and human sexuality more broadly which would likely not have appeared otherwise."13 The LC Policy and Standards Division (PSD) announced on March 22, 2016, that the heading Aliens was being changed to Noncitizens; that the heading Illegal aliens would be cancelled because it had become a pejorative term and two separate terms, Noncitizens and Unauthorized immigration, would be assigned together when needed to describe items dealing with people who are in a country illegally. According to the PSD, the above changes were made "in response to constituent requests." ${ }^{14}$ LC's efforts in maintaining $\mathrm{LCSH}$ as a viable and relevant resource for its patrons serve to validate its most noteworthy merits, which include its durability, its vigilance against bias, and its comprehensive nature. Johnson asserts, "Whatever these authors" misgivings, the retention and revision of LCSH as a standard is generally recommended; its usage is already so widespread and entrenched as to render its substitution generally impracticable."15

It is worth considering a different perspective in support of LCSH that focuses on how it affects professional catalogers, rather than library patrons. Just as patrons struggle to understand and use LCSH headings, catalogers also face a steep learning curve when attempting to master the intricacies of the LCSH to perform subject analysis. Taylor and Joudrey discuss the difficulties as they pertain to the teaching of subject cataloging in graduate school to future professional librarians. They specify the issues encountered in their advanced Subject Analysis course:

Due to the complex nature of the Library of Congress Subject Headings, three to four weeks are spent discussing the principles, procedures, and application of subject headings. . . . They are also instructed in how to write a properly constructed, viable subject-heading proposal. The LCSH unit is the longest unit in the semester-long course. It is generally the most difficult for students, as the procedures of subject heading work can be confusing and, at times, seemingly contradictory. ${ }^{16}$

Yet Taylor and Joudrey still emphasize the importance of teaching subject analysis:

It may also be tempting to downplay the importance of subject access, with the notion that keyword searching will resolve all our problems. That time is not here yet (and it may never be). Subject access, controlled vocabulary, and classification are still important and are grossly underutilized. ... It is more important than ever that we [educators] instill in our students an understanding of the necessity, importance, benefits, and joys of subject access to information. ${ }^{17}$ 
An alternative view has appeared in the current literature that acknowledges LCSH's value as an established subject access tool while seeking a more simplified and improved LCSH that is more suitable for use in next-generation catalogs. The new application, developed by OCLC with the cooperation of a subcommittee of the Subject Analysis Committee (SAC) of the Association for Library Collections \& Technical Services (ALCTS), is known as FAST (Faceted Application of Subject Terminology). FAST separates LCSH's controlled vocabulary structure into a less complex syntax that can be readily understood and used by anyone, particularly noncatalogers. While a detailed analysis of FAST is beyond this paper's scope, its development and related issues dealing with faceted approaches to LCSH are well documented in the literature, beginning with Chan and Hodge's seminal paper, "Entering the Millennium: A New Century for LCSH," and including Dean, Anderson and Hofmann, McGrath, Jin, and Bauer and Peterson. ${ }^{18}$

Since this paper's focus is how LCSH terms are created, it should be noted that few papers broach the subject of actual subject-heading proposals. Graham and Prager discuss the availability of funnel projects through the SACO program whereby participants work with institutions from neighboring areas or that catalog similar materials to contribute subject authority records for inclusion in LCSH. ${ }^{19}$ Kam points out the need for an alternative system, given the inadequacies of LCSH policies and services regarding the classification and access terms used for specific cultural groups in Canada. ${ }^{20}$ This paper offers another perspective, delving into the process of subject heading creation itself, outlining the steps necessary to achieve a successful LCSH proposal, and ultimately demonstrating that LCSH policies and procedures are, in fact, adequate for maintaining an inclusive controlled vocabulary.

\section{The LCSH Proposal Process}

LC has made a concerted effort to continually enhance operations for submitting new subject heading proposals. They have demonstrated their commitment by sharing their documentation for subject cataloging policies and procedures with the profession, instituting a subject authority cooperative cataloging program that welcomes the participation of non-LC catalogers, introducing more user-friendly online formats, and increasing their training and outreach with more conference presentations, workshops, and web documentation for catalogers.

\section{Background}

LC has actively maintained a list of subject heading entries since 1898 when, using ALA's "List of Subject Headings for Use in Dictionary Catalogs," LC catalogers in the new Catalogue Division began adding headings to the list as new topics were identified in their collections. In 1909, LC published parts of its own in-house list, "Subject Headings Used in the Dictionary Catalogues of the Library of Congress," which was eventually completed in 1914. As LC's list of subject headings expanded, the Catalogue Division developed principles of subject heading construction for use by their own staff. The list and its principles, applied by LC catalogers through the years, was renamed the Library of Congress Subject Headings in 1975, resulting in the international standard for controlled vocabularies. A more comprehensive account of LCSH's development is provided in The LCSH Century: One Hundred Years with the Library of Congress Subject Headings System, edited by Alva T. Stone. ${ }^{21}$

\section{LCSH Documentation}

The behind-the-scenes work performed by LC catalogers has always been vaguely understood by other catalogers. The general perception was that LC's catalogers were a group of highly specialized experts fortunate enough to be privy to the protocols and local training provided only to those who would become the overseers of the Subject Authority File-the resource that all other working catalogers routinely consult to do their work. It was not until the early 1980s that a shift in LC's subject heading operations exposed its catalogers' procedures to the general cataloging community. In truth, LC had already been sharing its bibliographic records with other libraries since 1902 by distributing printed copies of its catalog cards. However, LC's specific rules and procedures for subject cataloging were not available to external catalogers. Given that no formal code existed, the library community began to express a need for a subject cataloging guide comparable to the Anglo-American Cataloguing Rules, the standard for descriptive cataloging. In response, in 1984, LC began publishing Subject Cataloging Manual: Subject Headings (SCM:SH), its own internal instructions for subject cataloging. The manual provides detailed instructions for establishing and assigning subject headings, yet Chan cautions that it "is not cast in the form of a subject heading code." 22

LC's commitment to publishing its internal documentation with SCM:SH constitutes an important milestone in its efforts to ensure LCSH's sustainability for the broader community while enhancing and promoting the quality and usefulness of the Subject Authorities File. ${ }^{23}$ With more than one thousand guidelines (or "instruction sheets"), SCM:SH provides in-depth explanations for proposing and assigning subject headings from areas as general as Music and Fine Arts to more specific topics such as Awards or Sermons. The 2008 edition states, "Many cataloging practices that 


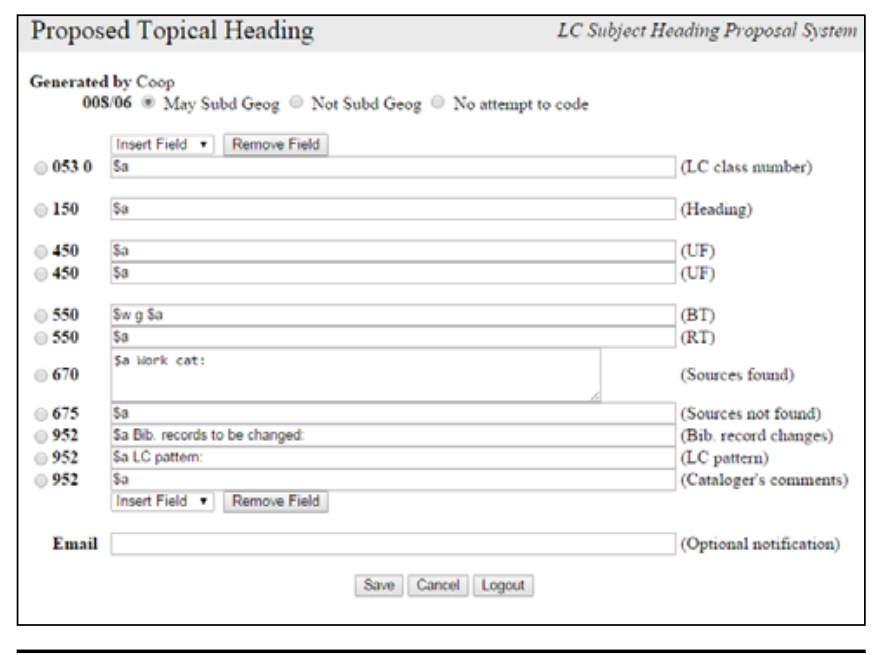

Figure 1. Topical Subject Heading Proposal Form in Classification Web

had been observed at the Library of Congress as part of its 'oral tradition' are now documented in writing for the first time." ${ }^{24}$ Once non-LC catalogers were aware of the cataloging policies and guidelines spelled out in LC's subject-cataloging documentation, they could begin to apply them as required within their own institutions, gain more proficiency with time, and contribute new subject headings on a routine basis. SCM:SH was renamed Subject Headings Manual (SHM) in fall 2008.

\section{Cooperative Cataloging Programs}

In 1994, LC created the Program for Cooperative Cataloging (PCC) to standardize training and shared cataloging standards for bibliographic records through the Bibliographic Record Cooperative Program (BIBCO) and for name authority records through the Name Authority Cooperative Program (NACO). LC invited outside catalogers to participate in the PCC to contribute bibliographic and authority records for other libraries to share, and to assist in the training necessary to make the PCC a cost-effective and affordable program for all participating libraries. In 1995, LC formed SACO, a component program of the PCC, and sponsored workshops for instruction in the concepts and procedures of subject-heading creation and proposals. LC emphasized that "Participation in SACO enables catalogers to develop appropriate subject headings to suit the collections of their institutions." ${ }^{25}$

The first SACO Participants' Manual was written by Adam Schiff in 2001 "as an overview of SACO policies and procedures and as a guide to creating SACO proposals." In contrast to the NACO and BIBCO programs, in which catalogers are required to undergo specialized training in bibliographic and name authority work, all libraries can submit subject-heading proposals via the online SACO system. Once received, each new subject proposal is reviewed and, if approved following a rigorous editorial process, incorporated into the online Subject Authority File. ${ }^{27}$

In 2007, the PCC introduced the online course, "Basic Subject Cataloging using LCSH," a joint venture with $\mathrm{SAC}$, which provides catalogers with formal instruction in subject-analysis principles and the application of LCSH fundamentals. The course is available via LC's "Catalogers Learning Workshop (CLW)," a website developed to "provide information professionals training resources related to the organization and classification of bibliographic information."28

\section{Online Subject-Heading Proposal System}

The SACO Proposal System is an online mechanism that is continually upgraded and improved, making the subjectheading proposal process considerably easier for all catalogers. The form used for topical subject-heading proposals is shown in figure $1 .{ }^{29}$

\section{SACO Workshops}

As with the resources available on the CLW website, another significant way that LC has proactively facilitated the educational development of catalogers who want to create new subject headings through SACO-sponsored workshops and mini-workshops presented at conferences and professional meetings. The SACO program website states, "The SACO Workshops offered at ALA typically include a basic workshop giving the fundamentals of constructing and submitting subject proposals on any topic and an advanced workshop treating the special techniques for particular topics. . . . For some participants, the SACO workshop is their first introduction to formal training for a PCC program. Attending SACO workshops gives new participants a glimpse into the role they may play in cooperative cataloging activities." ${ }^{\text {30 }}$

The author attended a SACO workshop, "Proposing New and Revised Topical Subject Headings," on June 25, 2015, at the University of San Francisco's Gleeson Library. Because of the excellent training and the encouragement received from the LC trainers, Janis L. Young and Paul Frank, the author was motivated to submit the two subjectheading proposals that are discussed in this paper.

\section{LCSH Formulation Principles}

From the time an original cataloger realizes that a new subject heading in the LC Subject Authority File is required, the steps that cataloger follows to formulate the 
subject-heading proposal and the subsequent processes by which that proposal is accepted or rejected are straightforward and uncomplicated. The entire submission process is done online using LC's subscription-based cataloging tools, Classification Web for the SACO Proposal System and Catalogers Desktop for access to $S H M$, where the specific proposal guidelines are found. Both resources are available through LC's Cataloging Distribution Service. ${ }^{31}$

It is necessary to highlight some of the basic principles that underlie LCSH's raison d'être and make it such a unique system. First, a new topic for inclusion in LCSH must have a fundamental reason and strong justification for consideration. As presented at the SACO workshop, proposing a heading has three main requirements:

1. The topic must be a new concept and different enough for researchers to want to search it.

2. Published works must deal with the subject (i.e., literary warrant).

3. Authoritative information must exist to support the establishment of the subject heading.

\section{LCSH Basic Principles}

\section{Literary Warrant}

The concept of literary warrant provides justification for the creation of a subject heading. As explained in the "Basic Subject Cataloging using LCSH" course, the two main aspects of literary warrant are "subject headings are created for use in cataloging and reflect the topics covered in a given collection," and "the terminology selected to formulate individual subject headings reflects the terminology used in current literature." 32

\section{Uniform Heading}

This is the concept that one heading represents one topic. In the Oxford Guide to Library Research, Thomas Mann, an LC reference librarian, provides a clear explanation: "Uniform heading addresses the problem of synonyms, variant phrases, and different-language terms being used to express the same concept and whose appearances may be scattered throughout the alphabet. A uniform heading also serves to round up the different aspects of a subject through the use of subdivisions of the lead term in the string." ${ }^{33}$ Figures 2 and 3 show the term Pirates as it appears in Classification Web.

\section{Unique Heading}

The principle of unique heading is a corollary of uniform heading, where each heading represents only one topic.
However, when the term used represents more than one concept, it is modified with a qualifier. The various concepts represented by the term Venus are illustrated in figure 4 .

\section{Specific Entry}

Mann explains specific entry as follows: "given a choice between using specific or general headings for a book, catalogers will usually choose the most specific possible headings for the book as a whole, rather than the more general headings available in the LCSH list." ${ }^{34}$ For example, the more specific subject heading for the book titled Portraits in Cataloging and Classification would be Catalogers not Librarians.

\section{Scope Match Specificity}

According to Mann, "If there was not a single term that expressed the subject of the book as a whole, the goal was to sum up the book in as few headings as possible-usually about three."35

\section{Precoordination}

In "Basic Subject Cataloging using LCSH," the LCSH system is referred to as "primarily a precoordinate system." Precoordination is defined as "combining elements into one heading string in anticipation of a search on that compound topic. ${ }^{p 36}$ The following precoordinated subject string would provide the most direct means of pinpointing works dealing with exhibitions of modern French furniture: Furniture design-France-History-20th century-Exhibitions. 


\section{Postcoordination}

The inverse principle, postcoordination, is applied when more complex topics cannot be expressed using precoordinated subject strings. The definition of postcoordination is "combining of headings or keywords by a searcher at the time he/she looks for materials." 37

As shown in "Basic Subject Cataloging using LCSH," the following combination of subject headings within one bibliographic record would lead a researcher to find a work on the architecture of Roman public baths in Great Britain:

\section{Baths, Roman-Great Britain \\ Architecture, Roman-Great Britain \\ Great Britain-Antiquities, Roman ${ }^{38}$}

This is also an example of how the scope match specificity principle (above) applies when the main topic of a book cannot be described using a single term. The next section illustrates how the author applied the principles just described to two different subject-heading proposals.

\section{Two Subject Heading Proposals}

\section{Proposal One: Libido}

The author corroborated Strader's findings that original catalogers are well-positioned to propose new subject headings for ETDs that provide contemporary research in emerging fields." 39 This was the case for the author who, fifteen years earlier, cataloged a dissertation on libido and found that LCSH lacked a subject heading for that term. In 2015, the author discovered that there still was no authorized subject heading Libido. The single occurrence of the word in LCSH was in the keyword index, and only because the term was used in a general Scope Note (under Sexual desire disorders) that read, "Here are entered works on hyperactive and hypoactive libido." The author noted this fact at the 2015 SACO workshop, where the LC trainers encouraged her to submit a subject-heading proposal and to apply the guidelines they provided at the workshop.

The proposal for the subject heading Libido that was submitted on July 6, 2015, via the LC Subject Heading Proposal System in Classification Web, which is provided in figure 5 .

The proposal was approved with modifications on October 14, 2015, and is shown in figure 6.

It is worth reiterating the three main requirements for submitting a subject heading proposal: (1) the topic must be a new concept in the LCSH; (2) published works must deal with that subject; and (3) enough authoritative information must be provided in reference sources to support the establishment of that subject heading. The author felt reassured that all three requirements were met when the proposal was prepared. Between the first proposal (figure 5) and the final subject heading record (figure 6), the following modifications were made:

1. The qualifier (Psychology) was removed from the 150 field in the main heading. ${ }^{40}$ The author had thought that the SHM guideline "cite a relevant and analogous existing LC heading as the pattern in a 952 field" was applicable. ${ }^{41}$ The pattern for Frigidity (Psychology) was used. The heading Libido did not require a qualifier.

2. Four variant terms (450 field) were added (in alphabetical order): Energy, sexual; Sex drive; Sexual drive; and Sexual energy.

3. Two broader terms (550 field) were added: Motivation (Psychology) and Sex (Psychology).

4. Two additional authoritative reference sources were added (in 670 fields) to justify the use of the variant terms in the 450 fields.

For each new subject-heading proposal, SACO specialists of the COOP Section verify that all the SHM guidelines are followed, that the appropriate variant terms are applied, and the all-important research has been conducted. If those criteria are not initially met, they will reject the proposal and notify the cataloger with the reasons why. Approved proposals are forwarded to the Data Integrity Section, where the term enters the editorial workflow and is ultimately included in the tentative list of subject heading proposals. From the initial proposal to its final acceptance and publication, the subject heading Libido (sh2015001702) was completed in three months and eight days.

\section{Proposal Two: Holocaust Deniers}

Holocaust deniers was the other subject-heading proposal that the author submitted. This proposal was not approved. Perhaps the topic of holocaust deniers presented a unique challenge in that it was not the main subject of a dissertation, nor did any published works deal specifically with deniers of the Holocaust. Nevertheless, the author was compelled to submit a proposal for that subject heading because Holocaust deniers did represent a new concept that was distinctive enough for researchers to want to search it. The term was needed to catalog certain items in a recently acquired collection of Holocaust materials, the Harry W. Mazal Holocaust Collection, at the University of Colorado Boulder.

The Mazal Holocaust Collection is "considered the world's largest privately owned Holocaust archive and the most significant U.S. collection outside the Holocaust museums in New York and Washington, D.C. ${ }^{\text {,42 }}$ This collection of more than twenty thousand publications and hundreds 
of thousands of documents includes materials that deal with distinct aspects of Holocaust denial, including works about the actual deniers themselves. Yet these materials cannot be made directly accessible to students or Holocaust researchers via subject catalog searches because LCSH only has two authorized subject headings for such works: Holocaust denial literature (for works that are actual specimens of Holocaust denial) and Holocaust denial (for works that discuss the concept of Holocaust denial). The initial proposal for Holocaust deniers was submitted on July 4, 2015 (see figure 7).

In the Summary of Decisions from their September 21, 2015, editorial meeting, LC's COOP team deemed the proposal to be unnecessary and gave the following explanation:

Holocaust deniers-The proposal cited only a single work being cataloged, which is about Holocaust denialism, and the methodology of the denial arguments. It does seem to discuss some deniers, but in order to talk about their beliefs, not about them as person. The work is therefore not about Holocaust deniers as a class of persons. It would be analogous to assigning Historians to a work about historical methodology that includes case studies of the methodology of particular historians. The work should be cataloged with the heading Holocaust denial. The proposal was not necessary. ${ }^{43}$

This demonstrates the thoroughness of COOP and SACO subject specialists' vetting process. They continually offer opportunities for catalogers to revise and resubmit proposals. During a SACO-At-Large Meeting held during the 2013 ALA Midwinter Meeting, one of the presentations featured a mini-workshop (Tips for Making Successful Subject Proposals) where six main categories of rejected proposals were summarized:

Figure 5. Initial Proposal for Libido

\begin{tabular}{|c|c|}
\hline 010 & $\operatorname{sh} 2015001702$ \\
\hline 040 & $\mathrm{CoU} \neq \mathrm{b}$ eng $\neq \mathrm{c} \mathrm{DLC}$ \\
\hline 150 & Libido \\
\hline 450 & Energy, Sexual \\
\hline 450 & Sex drive \\
\hline 450 & Sexual drive \\
\hline 450 & Sexual energy \\
\hline 550 & Motivation (Psychology) $\neq w g$ \\
\hline 550 & Sex (Psychology) $\neq w g$ \\
\hline 670 & $\begin{array}{l}\text { Work cat: Egan, R. Danielle. Becoming sexual, c2013: ¥b page } 150 \text { (One might posit that Freud's ideas, witten over a century ago, are a relic ... Freud's emphasis on the } \\
\text { necessity for redirecting a certain quantity of our libido, or sexual energy, towards the creation of art, new discoveries, the building of society - what he termed sublimation - } \\
\text { renders the interpretation of his work problematic ...) }\end{array}$ \\
\hline 670 & $\begin{array}{l}\text { MeSH, viewed July } 6,2015 \text { fb (Libido; the psychic drive or energy associated with sexual instinct in the broad sense (pleasure and love-object seeking). It may also connote } \\
\text { the psychic energy associated with instincts in general that motivate behavior) }\end{array}$ \\
\hline 670 & $\begin{array}{l}\text { Encyclopaedia Britannica, } 2015 \text { fb (Libido, concept originated by Sigmund Freud to signify the instinctual physiological or psychic energy associated with sexual urges and, } \\
\text { in his later witings, with all constructive human activity) }\end{array}$ \\
\hline 670 & $\begin{array}{l}\text { Merriam-Webster online, Jul. 10,2015 } \neq \mathrm{b} \text { (Libido: 1) instinctual psychic energy that in psychoanalytic theory is derived from primitive biological urges (as for sexual pleasure } \\
\text { or self-preservation) and that is expressed in conscious activity; 2) sexual drive) }\end{array}$ \\
\hline 670 & Wikipedia, Jul. 10, 2015 \#b (Libido, and colloquially sex drive, is a person's overall sexual drive or desire for sexual activity) \\
\hline
\end{tabular}

Figure 6. Approved Subject Heading for Libido (OCLC record-ARN: 10299924) 
1. SHM instructions were not followed (31 percent)

2. proposed heading was vague or not wellresearched (26 percent)

3. concept was already represented in the LCSH (23 percent)

4. more proposals were necessary (5 percent)

5. no precedent for the heading, references, etc. (4 percent)

6. Other (11 percent)

It appeared that Holocaust deniers had fallen within the second category, the 26 percent of rejected proposals that were vague and not well-researched.

The author undertook more in-depth research to help justify the proposed subject heading Holocaust deniers. She had failed to heed one of the caveats emphasized at the SACO workshop that she had attended: "It is seldom acceptable to cite only the work being cataloged." Another important point that is

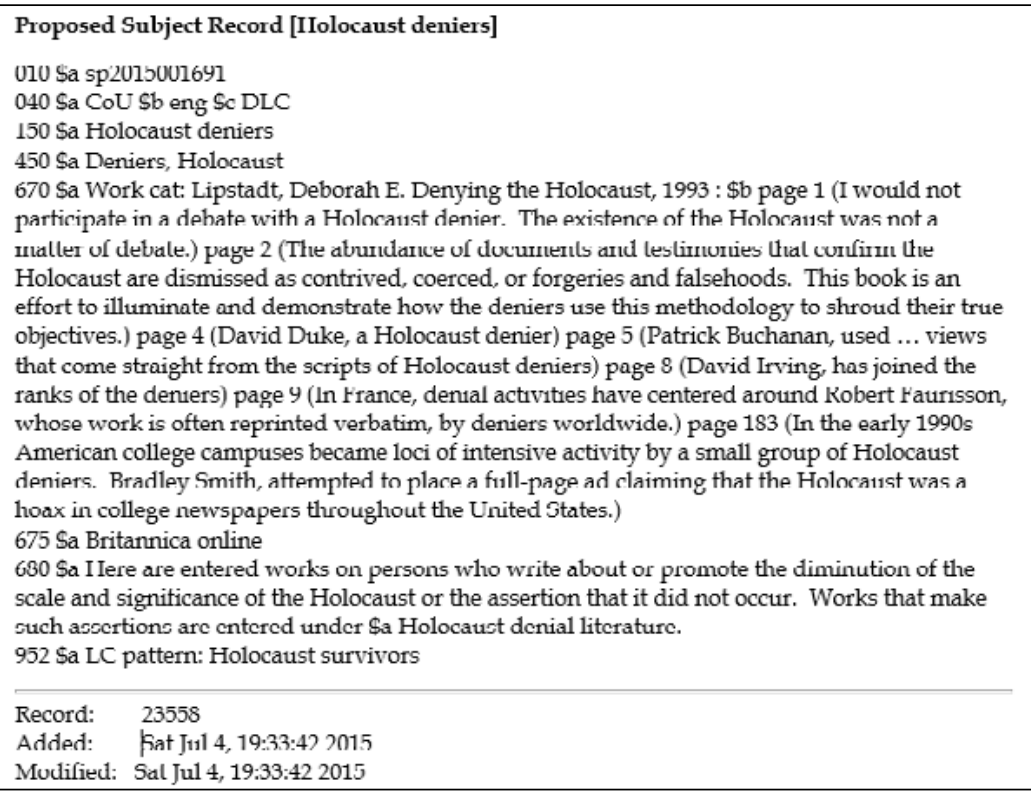

Figure 7. Initial Proposal for Holocaust Deniers

frequently emphasized at SACO workshops is that explicit guidelines for researching a subject-heading proposal are readily available in the SHM H 202 (Authority Research for Subject Heading Proposals). Catalogers should understand what is stated there:

The information recorded in the authority record serves three purposes: (1) to provide and indication of the relationship of the heading to the work being cataloged; (2) to provide information on the cataloger's choise of terminology for the heading, the UF and BT references, and the scope note (if provided); and (3) to provide definitions of terms, information on the intended scope and usage of the proposed heading, its relationship to, and distinction from, similar existing headings, and any peculiarities or other pertinent information about the heading.

The above information is used to guide the proposal through the editorial approval process and also serves as the permanent record for future reference and consultation. ${ }^{44}$

Given these detailed instructions, the author resubmitted an amended proposal (see figure 8) on December 8, 2015.

The resubmitted proposal included the necessary research required to "guide the proposal through the editorial approval process" as stipulated in H 202. Additional information included the following:

- A new "work cat" (referring to the item being cataloged) was added as the first 670 to demonstrate that
Lying about Hitler, the work in question, dealt with one Holocaust denier in particular: David Irving.

- The second 670 pointed to evidence in OCLC that Holocaust deniers was already being used as a subject heading - albeit in an "unauthorized" mannerin the 650 [subject field] of the bibliographic record (LCCN \#96105703) for Werner Cohn's Partners in Hate: Noam Chomsky and the Holocaust Deniers.

- The third 670 provides a second work cat to justify "how the cataloger decided on the terminology selected for the UF references." While Lenski's The Holocaust on Trial: The Case of Ernst Zundel never explicitly refers to Zundel as a Holocaust denier, he is repeatedly referred to as a Holocaust revisionist, thereby supporting the use of that term as a variant heading.

- The fourth 670 provides authoritative information in the form of the definition of Holocaust deniers as it appears online in the Holocaust Encyclopedia of the United States Holocaust Memorial Museum.

- The remaining 670s reference additional publications, that is, newspaper articles from the Atlantic and the New York Times, discussing current personalities considered Holocaust deniers.

- The 952 field provides a place for the cataloger to add comments explaining the need for the subject heading and the fact that, potentially, new deniers are being identified every day.

After the revised proposal for Holocaust deniers was submitted, the author encountered a new book in the 
Mazal Holocaust Collection, The Irving Judgment, published by Penguin in 2000. This work provided a detailed definition of the term in a chapter titled "What is Meant by the Term 'Holocaust denier?'” Unfortunately, a subjectheading proposal cannot be edited once it has been submitted. However, the COOP team is willing to include the new citation during their review process if the new information is relevant and the citation for the work is correctly formatted as a 670 note. The author provided the new data to the COOP team on March 7, 2016.

On May 2, 2016, the proposal was again rejected and deemed "not necessary" with a similar explanation (see the final paragraph below) given in the Summary of Decisions from SACO's editorial meeting on April 18, 2016:

\section{Holocaust deniers}

A proposal for this heading originally appeared on Tentative List 9 (2015). The Summary of Decisions for that list stated,

The proposal cited only a single work being cataloged, which is about Holocaust denialism, and the methodology of the denial arguments. It does seem to discuss some deniers, but in order to talk about their beliefs, not about them as persons. The work is therefore not about Holocaust deniers as a class of persons. It would be analogous to assigning Historians to a work about historical methodology that includes case studies of the methodology of particular historians. The work should be cataloged with the heading Holocaust denial. The proposal was not necessary.

The proposal on the current list provides evidence that the phrase Holocaust deniers is in use, but two of the works being cataloged are about court trials, to which a class of persons heading is not normally assigned. The other is a 20 -yearold book arguing that a well-known linguist and philosopher was a Holocaust denier. It has been adequately cataloged by assigning the name heading for the linguist along with Holocaust denial. The proposal was not necessary. ${ }^{45}$

The following communication from the Policy and Standards Division was received on May 10, 2016:

\section{Re: (Holocaust deniers)}

Your subject heading proposal, which appeared on monthly list 1604 , was not approved or is to

rd: 25346
010 sp2015002930

$040 \mathrm{Sa}$ CoU Sb eng Sc DLC

Sa Holocaust deniers

Sa Deruers, Holocaust

50 Sa Holocaust revisionists

670 Sa Work cat: Evans, Richard J. Lying about Hitler: History, Holocaust and the David Irving Trial, 2001 : Sb page 227 ([judgment of Judge Charles Gray] "Irving treated the historical evidence in a manner which fell far

chort of the standard to be expected of a conscientious historian." It was "incontrovertible" that "Irving qualifies as a Holocaust derier.")

670 Sa LCCN: 96105703 . Cohn, Werner. Partners in hate: Noam Chomsky and the Holocaust deniers, 1995. 670 Sa Lenski, Robert. The Holocaust on trial: the case of Emst Zundel, 1989: Sb Page I

... for some years now, a small but persistent group of people who call themselves

"revisionists" has been disputing the seemingly undisputable. They insist that the Holocaust is a myth.

Canada's best-known and most flamboyant revisionist is a gregarious and determined immigrant from

Germany's Black Forest region named Emst Zundel. For publishing a slim booklet entitled Did Six Million Really Die?, he was twice put on trial and convicted on a charge of spreading "false news.")

670 Sa United States Holocaust Memorial Museum, viewed December 8, 2015 Sb Holocaust encyclopedia Holocaust deniers ignore the overwhelming evidence of the event and insist that the Holocaust is a myth. invented by the Allies, the Soviet comunurists, and the Jews for their own ends.)

670 Sa The Atlantic, viewed December 8, 2015 Sb Grappling with Holocaust deniers by Conor Friedersdorf, July 22,2009 (Bradley Smith is much closer to the common perception of a classic Holocaust denier, singularly

(he with disproving the existence of the Nazi machinery of death.)

New York Times, viewed December 8, 2015 Sb Israel Fading, Iran's Leader Tells Deriers of Holocaust by Nazila Fathi, December 13, 2006 (A two-day gathering of Holocaust deniers and white supremacists ended Tuesday with President Mahmoud Ahmadinejad welcoming participants in his office and ing them lsael would not survive long.)

Sa The New York Times, viewed December 8, 2015 Sb Netanyahu Denounced for Saying Palestinian Inspired Holocaust by Jodi Rudoren, October 21, 2015 (Prof.

Moshe Zimmermanu, a specialist of German history at Hebrew University, said, "With this, Netanyahu joins a long line of people that we would call Holocaust deniers." Many Israelis have vilified Mr. [Mahmoud] Abbas as a holocaust denier because of a book he wrote that challenged the number of Jewish victims and accused of collaborating with Nazis to propel more Jews to what would become Israel.) 675 Sa Britannica online $25 \mathrm{Sa}$ The subject headings "Holocaust derial" and "Holocaust derial literature" are being used in the bib records for the works by Evans and Lenski. Since these deal with the deniers themselves, a more specific heading is needed to convey the true content. The 670 for Lenski is included to support the variant for "holocaust revisionists." Also, "new" Holocaust deniers (e.g.. Ahmadinejad, Abbas, etc.) are being identified very day, this would further substantiate the need for this proposal.

Added: Tue Dec 8, 2015

Modified: Tue Dec 8, 2015

Figure 8. Resubmitted Proposal for Holocaust Deniers

be resubmitted. For further information, see the Summary of Decisions of the editorial meeting or contact your Library of Congress Cooperative Cataloging team liaison.

\section{(Policy and Standards Division, Library of Congress) ${ }^{46}$}

The fact that the subject heading was not rejected, and could be resubmitted, gives the author hope that the right work will be discovered and that a new proposal can be reformulated and accepted at a future date. ${ }^{47}$

\section{Conclusion}

Exposing LCSH's policies and procedures to catalogers has had a profound effect on how new LCSH subject headings are proposed, approved, and implemented. It is up to original catalogers, working with LC's COOP experts and OCLC's Cooperative Online Resource Catalog team, to institute the needed changes to LCSH's structure that, as McGrath claims, "could create a vocabulary that better supports browsing and navigation in faceted interfaces. ${ }^{, 48}$ 
This paper has provided a glimpse into the process by which subject headings are conceived, researched, proposed, vetted, and integrated into LCSH-a perspective that has not been thoroughly treated in the literature and needs to be better understood by the general library community. This paper sought to show that, while controlled vocabularies and user-generated keywords and tags are complementary in many ways, and the use of faceted subject interfaces loom large over our community, the proven LCSH mechanism for creating and maintaining the largest controlled vocabulary system in the world will remain still unsurpassed while most library patrons (including librarians) appear to rely almost exclusively on keyword searching for library resources. Svenonius sums up this idea best: "There will always be a need for controlled precoordinate subject languages. As the pre-eminent of such languages, LCSH is not only a national treasure, providing access to many millions of documents, she is on her way to becoming a significant force for bibliographical control at an international level."

\section{References and Notes}

1. Lois Mai Chan, Cataloging and Classification: An Introduction, 2nd ed. (New York: McGraw-Hill, 1994), 413.

2. Arthur Maltby, Sayers' Manual of Classification for Librarians, 5th ed. (London: Andre Deutsch, 1975), 15.

3. Chan, Cataloging and Classification, 491.

4. Lois Mai Chan and Theodora Hodges, "Entering the Millennium: A New Century for LCSH," Cataloging \& Classification Quarterly 29, no. 1-2 (2000): 226.

5. C. Rockelle Strader, "Author-Assigned Keywords versus Library of Congress Subject Headings: Implications for the Cataloging of Electronic Theses and Dissertations," Library Resources \& Technical Services 53, no. 4 (2009): 250.

6. Tina Gross, Arlene G. Taylor, and Daniel N. Joudrey, "Still a Lot to Lose: The Role of Controlled Vocabulary in Keyword Searching," Cataloging \& Classification Quarterly 53, no. 1 (2015): 1-39; Strader, "Author-Assigned Keywords," 250; Theda Schwing, Sevim McCutcheon, and Margaret Beecher Maurer, "Uniqueness Matters: Author-Supplied Keywords and LCSH in the Library Catalog," Cataloging \& Classification Quarterly 50, no. 8 (2012): 903-28.

7. C. Rockelle Strader, "Citation Analysis: Do Age and Types of Materials Cited Correlate with Availability of Appropriate Library of Congress Headings?," Library Resources \& Technical Services 56, no. 4 (2012): 250.

8. David R. Gerhan, "LCSH in Vivo: Subject Searching Performance and Strategy in the OPAC Era," Journal of Academic Librarianship 15, no. 2 (1989): 87.

9. Radical Cataloging, ed. K. R. Roberto (Jefferson, NC: McFarland, 2008).

10. Schwing, McCutcheon, and Maurer, "Uniqueness Matters," 916.

11. Karen Calhoun, "The Changing Nature of the Catalog and its Integration with Other Discovery Tools," final report, Library of Congress, March 17, 2006, www.loc.gov/catdir /calhoun-report-final.pdf, 33. Twenty-three library and information professionals were interviewed for this report, which was commissioned by the Library of Congress in 2006 to explore options for revitalizing the research library cata$\log$, purportedly in decline, due to the fact that researchers and students were bypassing it in favor of other online discovery tools.

12. Sanford Berman, Prejudices and Antipathies: A Tract of Library of Congress Subjects Headings Concerning People (Metuchen, NJ: Scarecrow, 1971).

13. Matt Johnson, "A Hidden History of Queer Subject Access," in Radical Cataloging, 20.

14. Policy and Standards Division of the Library of Congress, "Library of Congress to Cancel the Subject Heading 'Illegal Aliens," Library of Congress, March 22, 2016, www.loc.gov /catdir/cpso/illegal-aliens-decision.pdf.

15. Johnson, "A Hidden History of Queer Subject Access," 21.

16. Arlene G. Taylor and Daniel N. Joudrey, "On Teaching Subject Cataloging," Cataloging \& Classification Quarterly 34, no. 1-2 (2002): 228.

17. Ibid., 231-32.

18. Lois Mai Chan and Theodora Hodges, "Entering the Millennium: A New Century for LCSH,” Journal of Internet Cataloging 4, no. 1-2 (2001): 225-34; Rebecca J. Dean, "FAST: Development of Simplified Headings for Metadata," Cataloging \& Classification Quarterly 39, no. 1-2 (2004): 33152; James D. Anderson and Melissa A. Hofmann, "A Fully Faceted Syntax for Library of Congress Subject Headings," Cataloging \& Classification Quarterly 43, no. 1 (2006): 7-38; Kelley McGrath, "Facet-Based Search and Navigation with LCSH: Problems and Opportunities," Code4Lib Journal 1 (2007), http://journal.code4lib.org/articles/23; Qiang Jin, "Is FAST the Right Direction for a New System of Subject Cataloging and Metadata?" Cataloging \& Classification Quarterly 45, no. 3 (2008): 91-110; Kathleen Bauer and Alice Peterson-Hart, "Does Faceted Display in a Library Catalog Increase Use of Subject Headings?," Library Hi Tech 30, no. 2 (2012): 347-58.

19. Suzanne R. Graham and George Prager, "Enriching the Vocabulary of Law: New Legal Subject Headings," AALL Spectrum 17, no. 2 (2012): 24.

20. D. Vanessa Kam, "Subject Headings for Aboriginals: The Power of Naming," Art Documentation: Journal of the Art Libraries Society of North America 26, no. 2 (2007): 18-22. 
21. Alva T. Stone, ed., The LCSH Century: One Hundred Years with the Library of Congress Subject Headings System (New York: Haworth, 2000), 1-15.

22. Chan, Cataloging and Classification, 171.

23. Library of Congress, Subject Cataloging Manual: Subject Headings, 5th ed. (Washington, DC: Library of Congress, Cataloging Distribution Service, 2008). The 2008 edition was the last print version. The manual is now freely available online with real-time updates at www.loc.gov/aba/pub lications/FreeSHM/freeshm.html.

24. Library of Congress, Subject Cataloging Manual, preface.

25. "About the SACO Workshops," SACO Program for Cooperative Cataloging, Library of Congress, accessed December 29, 2016, www.loc.gov/aba/pcc/saco/sacowkshops.html.

26. Adam L. Schiff for the Program for Cooperative Cataloging, SACO Participants' Manual (Washington, DC: Library of Congress, Cataloging Distribution Service, 2001), 1.

27. Library of Congress Authorities (database), Library of Congress, last updated May 18, 2016, http://authorities.loc.gov/.

28. "Catalogers Learning Workshop (CLW)," Program for Cooperative Cataloging, Library of Congress, last updated February 14, 2017, www.loc.gov/catworkshop/.

29. The form is available via Classification Web, https://classificationweb.net/Menu/subject.html. Catalogers without access to Classification Web and non-PCC members can find the interactive proposal system at the SACO site, www.loc.gov /aba/pcc/prop/proposal.html. A paper proposal form is also available for non-PCC institutions only at www.loc.gov/cat dir/cpso/lcshproposalformnew.pdf.

30. "About the SACO Workshops."

31. "Cataloging Distribution Service," Library of Congress, accessed December 29, 2016, www.loc.gov/cds/; also available via the LC Linked Data Service, http://id.loc.gov.

32. Lori Robare et al., eds., Basic Subject Catalogingusing LCSH: Instructor's Manual, rev. ed. (2007; repr., Washington, DC: Subject Analysis Committee of the Association for Library Collections \& Technical Services, 2011), 56, www.loc.gov /catworkshop/courses/basicsubject/pdf/LCSH_Instructor_ 2011.pdf.

33. Thomas Mann, The Oxford Guide to Library Research, 3rd ed. (New York: Oxford University Press, 2005), 19-20. Emphasis in original.
34. Mann, The Oxford Guide to Library Research, 27. Emphasis in original.

35. Ibid., 25.

36. Robare et al., Basic Subject Cataloging using LCSH, 64.

37. Ibid., 65

38. Ibid.

39. Strader, "Citation Analysis," 250.

40. In MARC authority records, the 150 field contains the established form of a topical term.

41. Library of Congress, Subject Cataloging Manual, H 202, section 2.

42. "Momentous Gift of Holocaust Archive to CU-Boulder Will Draw Scholars from around World," CU Boulder Today, March 4, 2014, www.colorado.edu/news/releases /2014/03/04/momentous-gift-holocaust-archive-cu-boulder -will-draw-scholars-around-world.

43. "Summary of Decisions, Editorial Meeting Number 9," Subject Authority Cooperative Program, Program for Cooperative Cataloging, Library of Congress, September 21, 2015, https://www.loc.gov/aba/pcc/saco/cpsoed/psd-150921.html. Emphasis in original.

44. Library of Congress, Subject Cataloging Manual, H 202, "Background."

45. "Summary of Decisions, Editorial Meeting Number 04," Subject Authority Cooperative Program, Program for Cooperative Cataloging, Library of Congress, April 18, 2016, https://www.loc.gov/aba/pcc/saco/cpsoed/psd-160418.html. Emphasis in original.

46. Policy and Standards Division, Library of Congress, personal communication to author, May 10, 2016.

47. As of this writing, the author submitted a new subject heading proposal on March 8, 2017. The work cat was titled Holocaust deniers and consisted of a compilation of Wikipedia articles with the biographies and works of fifty-three known Holocaust deniers. The subject heading Holocaust deniers was finally approved on May 15, 2017-one year and ten months after the initial subject-heading proposal had been submitted. See appendix.

48. McGrath, "Facet-Based Search and Navigation with LCSH."

49. Elaine Svenonius, "LCSH: Semantics, Syntax and Specificity," Cataloging \& Classification Quarterly 29, no. 1-2 (2000): 28. 


\section{Appendix. Authorized Subject Heading for Holocaust Deniers}

010 \$a sh2016002460

040 \$a CoU \$b eng \$c DLC \$d DLC

150 \$a Ilolocaust deniers

450 \$a Deniers, Holocaust

450 \$a IIolocaust revisionists

450 \$a Revisionists, Holocaust

550 \$w g \$a Persons

670 \$a Work cat: Holocaust deniers: Ernst Zundel, Fred A. Leuchter, David Irving, Mahmoud Ahmadinejad, Bobby Fischer, Nick Griffin, David Duke, 2010.

670 \$a United States Holocaust Memorial Museum, viewed October 25, 2016 \$b Holocaust encyclopedia (IIolocaust deniers ignore the overwhelming evidence of the event and insist that the IIolocaust is a myth, invented by the Allies, the Soviet communists, and the Jews for their own ends.)

670 \$a Lenski, Robert. The IIolocaust on trial: the case of Ernst Zundel, 1989: \$b Page I ( . . for some years now, a small but persistent group of people who call themselves "revisionists" has been disputing the seemingly undisputable. They insist that the IIolocaust is a myth.)

670 Sa 96105703: Cohn, Werner. Partners in hate: Noam Chomsky and the Holocaust deniers, 1995.

670 \$a The New York Times, viewed October 25, 2016 Sb Israel Fading, Iran's Leader Tells Deniers of Holocaust by Nazila Fathi, December 13, 2006 (A two-day gathering of Holocaust deniers and white supremacists ended Tuesday with President Malumoud Almmadinejad welcoming participants in his office and telling them Israel would not survive long.)

675 \$a Britannica online

Record: 342962

Added: Mon May 15 09:36:37 2017

Modified: Wed Jun 11 11:39:33 2017 